Land Use Policy 52 (2016) pp: 382-391

\title{
Institutional impacts on the resilience of mountain grasslands: an analysis based on three European case studies
}

Markus Schermer a*, Ika Darnhofer b, Karoline Daugstad c, Marine Gabilletd, Sandra Lavorel d, Melanie Steinbacher a

*Corresponding author: markus.schermer@uibk.ac.at Tel.++43(0)512.507.73413, Fax: $+43(0) 512.507 .73599$

a Department of Sociology, Mountain Agriculture Research Centre, University Innsbruck, Universitätsstrasse 15, 6020 Innsbruck, Austria

b Institute of Agricultural and Forestry Economics, Department of Economic and Social Sciences, BOKU - Univ. of Natural Resources and Life Sciences, Feistmantelstr. 4, 1180 Vienna, Austria

c Department of Geography, Norwegian University of Science and Technology, NTNU NO7491 Trondheim, Norway

d Laboratoire d'Ecologie Alpine, Université Joseph Fourier, BP 53, 38041 Grenoble Cedex 9 France

\begin{abstract}
Over the centuries, specific farming practices shaped permanent grasslands in mountains. With socio-economic change, farming practices have changed and with them the landscape. Over time, food production has been increasingly decoupled from the preservation of permanent grassland, endangering the delivery of crucial ecosystem services. This contribution looks into the role of institutions - including normative, regulative and cultural-cognitive elements - in preserving current bundles of ecosystem services provided by mountain grasslands. In particular, we investigate how such institutions affect farmers' management choices. Based on a review of scientific literature and empirical data from three case studies, we compare institutions in Austria, France and Norway. The cases represent different modes of multi-level governance (EU and non-EU), different grassland management practices, linked to different farming systems (dairy, breeding, rearing of heifers, suckler cow and sheep production) and different socio-economic conditions. The results underpin that ecological insights into the impact of farming practices on the ecology of grassland need to be combined with an understanding of the complex institutional interactions that affect farming practices, to ensure the resilience of mountain grasslands. If the design of regulatory measures considers both changing dynamics, it may enable farms to adapt and transform while maintaining traditional grassland management practices.
\end{abstract}

Keywords: marginal mountain grasslands, socio-ecological resilience, institutions, farm management practices 


\section{Introduction/Background}

Mountain ecosystems provide a vast array of goods and services to society, both to people living in mountainous areas and to people living in urban centers (e.g. MA, 2005; TEEB, 2010; GrêtRegamey et al., 2011). Yet, these mountain ecosystems are sensitive to current pressures (e.g. Körner, 2000; Schröter et al., 2005; Engler et al., 2011) which manifest themselves in changes of land use practices, infrastructure development, unsustainable tourism and fragmentation of habitats (EEA, 2002; Grêt-Regamey et al., 2011). These pressures in turn are local expressions of global socio-economic and climatic changes.

European marginal grasslands are biodiversity hot-spots owing to biophysical constraints, natural heterogeneity, and centuries of agriculture. Currently it is not clear to what extend these unique systems are affected by ongoing environmental and societal changes, or if they have developed a high resilience over their history of co-evolution. The critical thresholds - beyond which radical changes in the ecosystem are likely- are unknown, and their prediction fraught5 with uncertainty. This uncertainty lies largely in the poor knowledge of resilience mechanisms of both the ecological and social sub-systems, as well as those underpinning robustness or vulnerability of the entire system, which is coupled through land use decisions and ecosystem services.

Resolving this uncertainty is essential to guide policy development, especially in the areas of biodiversity conservation, agri-environmental and rural development. These different policies may have conflicting objectives, affect farmers' grassland management choices and thus threaten the delivery of the ecosystem services, which society demands from permanent grassland in mountain regions.

Generally, four types of ecosystem services can be distinguished: provisioning services, including all products we obtain from an ecosystem; regulating services, which include benefits from the regulation of ecosystem processes; cultural services, focusing on the immaterial aspects, and supporting services, which are needed to provide all other ecosystem services (MA, 2005). Policies influence the delivery of these services, not least because they have induced a decoupling of provisioning services (i.e. food production') from regulating and cultural services linked to mountain grasslands. Within the Common Agricultural Policy of the European Union (CAP) this decoupling is mirrored in the division between measures supporting competitiveness of food production, measures safeguarding rural development and measures supporting traditional practices, which provide aesthetic grassland landscapes, clean water and carbon sequestration.

However, besides policy interventions there are a number of economic, societal or technological incentives and constraints influencing the social-ecological resilience of farms and the management of grasslands (Young et al., 2008). This paper aims to assess how diverse formal and informal institutions impact the management of marginal grasslands, thereby affecting the delivery of specific highly interrelated and interdependent ecosystem services.

Building on case studies from Austria, France and Norway we analyze the impact of different frameworks for traditional management practices on marginal grasslands. We highlight the importance of integrating different scales (grassland, farm, landscape) to understand the dynamics of diverse drivers influencing management choices. The management of marginal grassland is crucially connected to the management of more productive parts of a farm, which is embedded within economic and technological changes that are in turn linked to wider rural development (e.g. the possibilities to generate off-farm income

In the following section we first present our analytical framework, building on the concepts of resilience, institutions and a polycentric governance system. We then provide a short account of our approach to data collection and a description of the empirical case study regions in 
Austria, France and Norway. Building on these cases, we analyze the interplay of culturalcognitive, normative and regulative institutions with farmers' practices in the section that follows. In the last section we look into the effects of these institutions on traditional management methods and thus on the resilience of permanent mountain grasslands.

\section{Analytical framework}

To conceptualize interactions between the social and ecological domains, we use the concept of social-ecological resilience. Walker et al. (2004, p1) define resilience as "the capacity of a system to absorb disturbance and reorganize while undergoing change so as to still retain essentially the same function, structure, identity, and feedbacks". While initially developed by ecologists, it is now widely used to study how interactions between ecological and social subsystems induce and drive changes (Adger, 2000; Folke, 2006; Davidson, 2010; Rickards and Howden 2012). The concept of resilience builds on an understanding of eco-systems as dynamic and evolving under the influence of external social forces. Moreover, a system is understood as embedded in hierarchies, with slow and fast changes at larger and smaller scales (Holling, 2001). This helps structuring the assessment of drivers of change at different spatial scales acting at faster or slower rates.

Applying resilience thinking to agriculture, Darnhofer (2014) distinguishes three capabilities that characterize resilient farms: the ability to buffer shocks, the ability to adapt through implementing marginal changes, and the ability to transform through implementing radical change. Indeed, while in literature on ecosystems the focus is often on maintaining an ecosystem within thresholds, arguably in social systems adaptability and transformability play a more important role. Thus while farms need to be able to buffer or absorb shocks in the short term (e.g. after an extreme weather event or a sudden spike in prices), over the medium and long-term, they also need to be able to adapt or even transform.

In this study, the unit of our analysis is not the entire farm, but mountain grasslands. This includes meadows and pastures close to the homestead at the valley bottoms, as well as extensively grazed pastures, which are usually at higher altitudes, often on steep slopes.

The ecosystems of marginal grasslands have specific species compositions and provide specific ecosystem services. We use resilience to conceptualize these ecosystems as dynamic and as being influenced by diverse social processes at different scales, e.g. at farm, regional, national and international level. To avoid shifts in species composition, for instance through scrub encroachment, their continued use is crucial. In other words, they depend on the integration of marginal grasslands into farming systems as sources of fodder, which in turn depends on the viability of farming in the region.

Thus, we specifically examine farming practices that contribute to maintaining such permanent grasslands in mountain areas. From an ecological point of view, their biodiversity is linked to traditional extensive farming practices. These are threatened by both abandonment (collapse of the social system represented by active farming) and by intensification (maintenance of the social system of the farm, but collapse of the traditional farming practices). Grassland resilience thus results from the interactions between the social and ecological sub-systems: unless the social sub-system (and the grassland management practices linked to it) is maintained, the persistence of the ecological sub-system will be threatened.

Figure: 1 Different forms of institutions and dynamics at different scales impact on the management of marginal grassland 


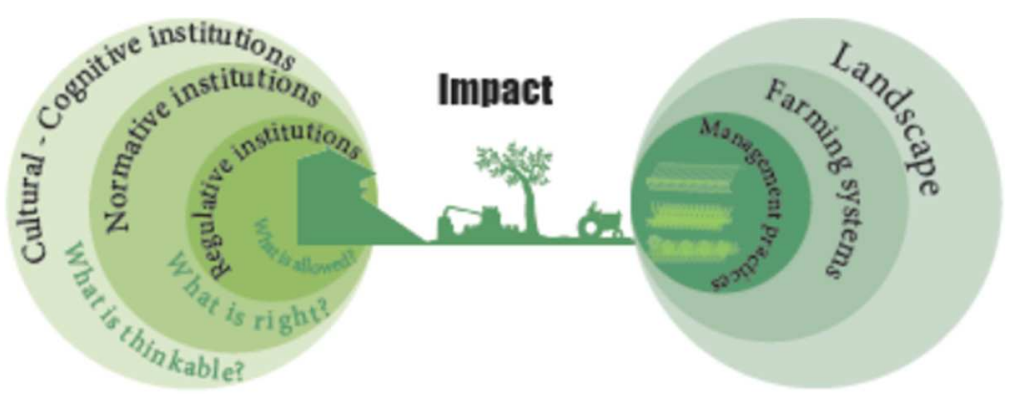

A web of insitutions (Fig.1) influences the maintenance of specific grassland management practices. Institutions denote rules governing the behavior of actors (North, 1990; Scott, 2008), not physical structures or organizations. North (1990) views institutions as the 'rules of the game' while organizations are the actors on the field. Institutions can be formal, as in the case of legal restrictions; or informal, as in the case of shared societal norms and non-codified rules of good practice. Scott (2008, p: 48) defines institutions as "comprised of regulative, normative and cultural-cognitive elements that, together with associated activities and resources, provide stability and meaning to social life." This definition distinguishes three elements of institutions, each of which involves different capacities. Firstly, there are regulatory elements. These involve the capacity to establish regulations and laws. They are coercive and disobedience is sanctioned. People comply out of fear of punishment by legal sanctions. In connection to farmers' practices, they are not restricted to regulations but include the prescriptions to be eligible for transfer payments and subsidies. Secondly, there are normative elements. They involve the creation of binding expectations to follow social obligations. Non-compliance does not result in punishment but rather in shame, as norms are morally governed. Thirdly, there are cultural-cognitive elements. These involve the creation of shared understandings that are taken for granted. They result in common beliefs and shared logics of actions. Acting in opposition to cultural cognitive elements of institutions creates confusion, while compliance is culturally rewarded.

This institutional environment acts at different levels, forming a multilevel governance system. Pahl-Wostl (2009) uses the notion of a polycentric governance system, which she defines as "complex, modular systems where differently sized governance units with different purpose, organization, spatial location interact to form together a largely self-organized governance regime" (Pahl-Wostl 2009, p: 257). For example cultural-cognitive institutions that give meaning to grassland farming at local level may inform normative institutions like governments, market actors and civil society which lobby for regulations at (supra-)national levels. Regulations are negotiated mostly by professional organizations, which are informed by local farming practices, which in itself are guided by particular cultural cognitive frames that have evolved over centuries.

Normative elements also act at a global level, where there is a largely unreflected dominant belief that economic growth is necessary to increase wealth; or that an increase of food production is required to feed the growing world population. This leads to neoliberal and neoproductivist claims (Burton and Wilson, 2012), which normatively push for deregulation, resulting in price pressure on agricultural markets. Such dominant normative claims are contested by NGOs and civil society actors, who promote regulations that enforce to preserve nature, so as to enable it to deliver a broad range of environmental services.

At the EU or national level government actors are paramount. Normative forces of market and civil society actors influence them via lobbying or professional organizations. They establish or reinforce norms of what is desirable (esp. landscape for ecological and recreational value), which find their expression in regulations. Regulations take the form of direct payments, some 
of which are linked to agri-environment measures. These have strong influence on grassland management, given the dependence of farms on direct payments.

Finally, on an individual or a community level there are again normative and cultural cognitive institutions within wider society, expressed for instance in the demand for regional specialty food. Similarly cultural cognitive elements within the farming community influence who is considered to be a 'good farmer' e.g. in cattle shows (Burton 2004, Sutherland and Darnhofer, 2012)

In the following section we briefly summarize our methods of data collection and characterize the three study sites before we continue analyzing how the polycentric web of institutions influences grassland management practices in each site.

\section{The three case study regions: farmers' practices and current trends}

\subsection{Data sources and case study method}

In each country (Austria, France and Norway), we conducted one case study during summer and autumn 2013. The cases were selected to offer contrasting institutional settings (EU and non-EU) and to cover a diversity of grassland types. Their common denominator is that they represent valuable ecosystems and at the same time important components of the local mountain farming systems.

Our case study methodology allowed for site-specific adaptations, taking into account different prior research activities and knowledge of the three research teams.

In a first step the research teams in each country scrutinized earlier research reports, scientific publications and governments documents, to describe in national reports the societal expectations into mountain grassland as well as to describe the polycentric web of institutions and organizations and the national and regional policy instruments.

In order to get deeper insights into local farming systems and their interrelations with various drivers we conducted semi-structured interviews with farmers and key informants from various stakeholder groups, including members of the advisory service, local and regional administration, tourism sector etc. as appropriate at each site. Together with statistical data, this allowed to describe the various local farming systems and current trends over the past 30-40 years. These regional case study reports contained furthermore the constellation of influencing actors and institutions.

The national reports together with the regional case study reports provide empirical the basis for the following chapters.

\subsection{The three case study regions.}

The Austrian case study of Neustift is located in the Stubai valley, about $30 \mathrm{~km}$ south of Innsbruck, the capital of Tyrol. The growth of the city region of Innsbruck has an impact on Neustift, not least by creating settlement pressure by commuters. A second decisive influence comes from summer and winter tourism, as a glacier offers year-round skiing facilities. Currently there are 168 active farms, each managing an average of 35 ha agricultural land. The most common farming system for full-time farmers is cattle breeding, in combination with dairy farming. However, some $80 \%$ of farmers are part-time farmers, increasingly specializing on sheep or suckler cows. So far, part time farming with integration into tourism has resulted in a rather stable farming structure with less farm closure than on a district or state level. 
The management of grassland differs according to its location: in the relatively flat valley bottom, meadows are cut two or three times and manure is applied. The alpine pastures are used for grazing in summer and are not fertilized. Meadows in the valleys are often used as transitional pastures in spring and autumn before and after the alpine pasture season. Most farms participate in the agri-environmental program and refrain from the use of artificial fertilizers and pesticides. A substantial part of alpine pastures is managed by a communal farmers' association, which also manages communal grazing grounds in the valley. Many farms have their own private or collective alpine pasture, besides having grazing rights on communal pastures.

So far, grassland management is still generally extensive. However, two diverging trends are discernible: in the valley bottom, management practices are intensifying, driven by a slow reduction in the number of farms. Fewer farms means larger farms and larger herds, which is often connected with more intensive feeding (use of concentrate), which in turn increases the nutrient content of slurry. Moreover the spread of free-run stables promotes a shift from solid to liquid manuring. Alpine pastures are increasingly stocked with calves and heifers (rather than dairy cows) so that they can be managed by occasional visits. The more extensive use of the alpine pastures means that some parts are increasingly abandoned and prone to scrub encroachment, as it had happened to most extensive mountain meadows already over the last 50 years.

The French case study focusses on the Lautaret, close to the Ecrins National Park in the Southern French Alps. The site includes two municipalities located on each side of the Lautaret pass: Villar d'Arêne (1600 meters above sea level) with eight farms and Monêtier-les-Bains (1500 m. a. s. 1.) with eighteen farms. Tourism is an important economic activity in the region, linked to the Serre Chevalier and Deux Alpes ski resorts and the numerous opportunities for outdoor activity (Quétier et al., 2010). Agriculture relies on livestock farming (heifer and sheep rearing) and the vast majority of agricultural land is permanent grassland (Deboeuf, 2009; Lamarque, 2012). Labor availability is restricted to the farmer himself with occasional help from family members or external labor force, e.g. for harvesting. During winter, some farmers work at the ski resorts. Cattle farmers in the Lautaret are closely tied to partner dairy farms in the Beaufort and Abondance areas. They buy the calves from them and resell the heifers to their original owners after three years. Whereas the cattle are local or come from within the 'départment', large flocks of sheep complement local sheep herds on summer pastures as part of large transhumance systems. In winter most local sheep farmers keep at least a part of their flock locally, which is fed with the fodder mowed during summer. Some local farmers have developed a winter transhumance for all or a part of their flock to lower altitude areas as far as the Provence, allowing them to increase their flock size without additional fodder of barn space.

Former arable land on terraced slopes had been converted into grassland during the first half of the $20^{\text {th }}$ century and is now grazed or - if accessible to machinery - mown. Transitional pastures (grazed in spring and autumn before and after mowing) and meadows are private, whereas summer pastures belong to the municipalities. In Villar d'Arêne, all fields (mown and grazed) are pooled into a communal organization (Association Foncière Pastorale, AFP) which allocates parcels to farmers (Deboeuf, 2009). In Monêtier-les-Bains, private and communal land tenure managements rest upon individual agreements, rooted in customary rules of land tenure management.

Between 1980 and 2000 the number of farms was reduced by about half, while the number of cattle increased significantly and the number of sheep decreased slightly. The number of farms has now stabilized at a low level, but the increased area per farm resulted in a shift from mowing to very extensive grazing. The consequence may be a loss of transitional pastures through shrub encroachment. In Monêtier les Bains $61 \%$ of transitional pastures already have gained 
significant woody cover over the last 50 years. The communal summer pastures however, are not threatened by abandonment, as they are embedded in large transhumance movements. Their utilization may even increase in the context of climate change (Nettier et al., 2010). Local stakeholders are worried about a trend toward a "ranching" system, where local farms give ground to transhumant farmers, threatening the maintenance of mowing practices, which are highly valued culturally and ecologically (Quétier et al., 2007).

The Norwegian study site focusses on Oppdal is a municipality located in a mountainous area in mid-Norway. Oppdal is situated 545 meters above sea level. Approximately $50 \%$ of the land area is under some form of protection (Oppdal Municipality 2013). Tourism plays an important role, linked to the Oppdal Ski Centre. There are some 250 active farms, which focus on sheep production for meat (mutton) and dairy. Traditionally full-time farmers are dairy farmers, while part-time farmers keep sheep.

There is an ongoing structural change, the number of farms has decreased by $20 \%$ over the last 10 years, and the number of active dairy farmers has even decreased by $50 \%$. On the other hand sheep and suckler cow production systems have picked up. By law, the municipality must ensure that farms with more than 0,5 ha of cultivated land stay in production; if farmers are not working it by themselves they are obliged to rent the land to other active farms.

Regarding the grassland, a distinction is made between 'infields' and 'outfields'. The 'infields' cover approximately $30 \%$ of the land, and are generally the fields close to the farm. Most infields are mown to produce silage or hay twice during summer, and some of them are also grazed in spring and autumn. The 'outfields' cover some $70 \%$ of the land area. They are not fields as such, but mainly natural pastures in forests, moors, and on alpine land. They are commons and grazing management is organized in teams. Traditionally, the outfields have been important grazing grounds for cattle and sheep during the summer months.

While all infields are still managed, over the last decades the number of grazing cattle has decreased in the outfields, leading to scub encroachment and forest invading former open land. In some areas sheep grazing is partly able to prevent this, but in areas not favored by sheep, scrub encroachment can already be observed.

In summary, in all three cases traditional practices ensured that marginal grassland was used through grazing in the summer months. However, these traditions are slowly being abandoned, leading to scrub encroachment and loss of open space. However, what happens on marginal grasslands cannot be seen independently from grasslands that are more productive. In Austria the alpine pastures depend on the economic situation of farming in the valley; in Lautaret the heifer system is dependent on the farms in cheese making regions and the sheep system is part of large-scale transhumance practices; in Norway the conditions of outfields are influenced by what happens on the infields. Furthermore, in all three cases, the general economic situation and the labor organization is decisive for marketing opportunities as well as on- and off-farm employment opportunities thus affecting labor organization (Tab. 1). Farm succession depends on both traditional values and the economic attractiveness of farming. Thus, the management of the marginal mountain grassland is closely linked to market forces, to policy interventions, and to broader societal perceptions.

Table 1: Overview of the trends affecting grassland management practices

\begin{tabular}{|l|l|l|l|}
\hline & Neustift (Austria) & Lautaret (France) & Oppdal (Norway) \\
\hline Economics & $\begin{array}{l}\text { Farm economy linked to } \\
\text { pluri-activity (tourism) } \\
\text { and to CAP payments }\end{array}$ & $\begin{array}{l}\text { Farm income linked to } \\
\text { pluri-activity (during }\end{array}$ & $\begin{array}{l}\text { Fulltime farming dairy, } \\
\text { part time sheep } \\
\text { production }\end{array}$ \\
\hline
\end{tabular}




\begin{tabular}{|c|c|c|c|}
\hline & & $\begin{array}{l}\text { winter) and to CAP } \\
\text { payments. }\end{array}$ & \\
\hline Organization & $\begin{array}{l}\text { Private in the valley; } \\
\text { private and collective on } \\
\text { mountain pastures }\end{array}$ & $\begin{array}{l}\text { Private and communal / } \\
\text { collective depending of } \\
\text { the locality }\end{array}$ & $\begin{array}{l}\text { Private on infields, } \\
\text { collective on outfields }\end{array}$ \\
\hline $\begin{array}{l}\text { Socio-economic } \\
\text { trends }\end{array}$ & $\begin{array}{l}\text { Polarization into full- } \\
\text { time dairy farmers with } \\
\text { increased stock and part } \\
\text { time farmers with } \\
\text { suckler cow or sheep } \\
\text { production. } \\
\text { Farmers are pluri-active } \\
\text { with all year off- farm } \\
\text { employment or holidays } \\
\text { on farm. Direct } \\
\text { marketing often } \\
\text { connected to tourism }\end{array}$ & $\begin{array}{l}\text { Conversion from farming } \\
\text { to 'ranching'. Fewer } \\
\text { animals wintered locally, } \\
\text { thus less mowing. } \\
\text { Increasing pressure on } \\
\text { summer pastures by } \\
\text { transhumant herders. } \\
\text { Labor shortage } \\
\text { constrains direct } \\
\text { marketing. }\end{array}$ & $\begin{array}{l}\text { Rapid structural change, } \\
\text { decrease in the number } \\
\text { of farms; shiftfrom dairy } \\
\text { to suckler cow and sheep }\end{array}$ \\
\hline $\begin{array}{l}\text { Impact on productive } \\
\text { grassland }\end{array}$ & $\begin{array}{l}\text { Intensification on } \\
\text { productive meadows. } \\
\text { Land competition with } \\
\text { settlements }\end{array}$ & $\begin{array}{l}\text { Shift from mowing to } \\
\text { grazing, decreases } \\
\text { biodiversity. Land } \\
\text { competition with } \\
\text { settlement }\end{array}$ & $\begin{array}{l}\text { Infields are still } \\
\text { managed, structural } \\
\text { change leads to strong } \\
\text { increase of rented land }\end{array}$ \\
\hline $\begin{array}{l}\text { Impact on marginal } \\
\text { grassland }\end{array}$ & $\begin{array}{l}\text { Extensive use by sheep } \\
\text { and suckler cows, calves } \\
\text { and heifers, management } \\
\text { from homestead through } \\
\text { short visits, partly } \\
\text { abandonment }\end{array}$ & $\begin{array}{l}\text { Summer pastures } \\
\text { managed by large } \\
\text { transhumant flocks; very } \\
\text { extensive use of } \\
\text { transitional pastures } \\
\text { leads to shrub } \\
\text { encroachment }\end{array}$ & $\begin{array}{l}\text { Abandonment of } \\
\text { 'outfields', leading to } \\
\text { scrub encroachment }\end{array}$ \\
\hline
\end{tabular}

\section{The web of institutions affecting grassland management practices}

As the brief description of the three case studies indicates, a range of institutions - especially social organization and agricultural policies - influence farmers' practices. Combining the results of the case studies with a review of literature, allows us to assess how institutions representing societal claims shape the framing of farmers' practices.

\subsection{Cultural-cognitive institutions}

Cultural-cognitive institutions define what is thinkable and what is unthinkable (Pahl-Wostl, 2009). Concerning permanent mountain grasslands, this refers to the general societal call to 'keep the landscape open'. In Austria, and at an EU-level, this translates into the general political goal to maintain an 'area-wide' or 'spatially comprehensive' agriculture. In Norway the corresponding and very explicit claim is the 'openness' of the landscape. This claim includes the basic assumption that the 'openness' of the landscape can be guaranteed by a combination of landscape preservation and agricultural production. In our three study areas, this concerns extensive mountain meadows in Austria, transitional pastures in France and outfields in Norway. Shifts in their management and use are already being recognized by society and provide a justification for normative and regulative interventions at both national and regional scale.

At the local scale these cultural-cognitive framings are complemented by the dominant perceptions held by the wider agricultural community. These framings, while not being 
codified, nonetheless define which practices characterize a 'good farmer' and what is socially valued. For instance, cattle breeders perceive free run barns as problematic, as they lead to dirtier animals; thus breeders often prefer tethered housing, despite animal welfare considerations. Especially in regions such as Neustift, where about half of all farmers keeping cattle are member of a breeders' association, farmers' practices are informed by the associations' value system, i.e. how animals should be kept and fed and whether or not they should be put on alpine pastures during summer. Breeders associations develop measurements of 'success', which form a major source of social recognition, and grant visible signs to those farmers who comply with these expectations. Farmers are proud to display the symbols on their barn (e.g. related to the average milk yield or to the rank achieved on cattle shows).

In the French case similar cultural values are reported, related to the necessity to mow and maintain terraces despite technical problems. Farmers consider mowing a constitutive practice that distinguishes them from transhumant shepherds. However, the formative power of such values may gradually change. Recently two young farmers have established in Villar d'Arêne (Lautaret), which are not likely to follow the traditional norms. For example, one of them raises goats for cheese production and is not interested in mowing. Some farmers consciously distance themselves from their peers and seek external recognition, e.g. through their direct-marketing customers. To them this positive feedback is a more important motivation for their extensive or traditional practices, than the financial aspects of direct-marketing.

As all farmers are also part of a local community, cultural values of the non-farming members of the community, as well as NGOs or tourism operators, e.g. regarding hay making, sending cows on alpine pastures during the summer, will also influence farmers' practices.

\subsection{Normative institutions}

Normative institutions, defining what is right and what is wrong, may change over a relatively short time (Pahl-Wostl, 2009). Since the Second World War farmers have already witnessed productivist, post-productivist and recently neo-productivist paradigms. The current neoliberal and neo-productivist (Burton and Wilson, 2012) global paradigm is contrasted with the acknowledgement of limited nature and natural resources. This contradiction results in diverging normative claims by different societal groups. We can trace these competing claims through the list of objectives brought forward as arguments for sustaining farming in permanent mountain grassland in each of the three countries.

In Austria an analysis of various policy documents shows competing agrarian, socio-economic and landscape ecology goals (Pistrich and Wyrtrzens, 2005). Within the agrarian 'Leitbilder' two different orientations are found, one proposing an agriculture that can compete on global markets, the other focusing on multifunctionality. The result is a polarization into productionoriented intensively used grassland and protection-oriented extensive grassland (Groier, 2007). The multifunctionality of farming and associated non-marketable benefits justifies societal transfer payments (Pötsch, 2009, Heißenhuber, 2010). These payments are crucial for farmers to continue farming and thus for the preservation of permanent grassland in less favored areas (Hovorka, 2011). To maintain farming is also justified by socio-economic goals such as sustainable provisioning of food, food security in times of crisis, protection against natural hazards, contribution to regional identity and culture. Specific interests include preservation of cultural landscape, access to recreational areas, preservation of endemic wildlife etc. Landscape ecology goals relate to the concept of sustainability, preservation of natural resources, species and biotope conservation (Pistrich und Wyrtrzens, 2005).

For Norway, the multiple landscape values of grasslands has been underlined in a number of studies (see for example Daugstad et al., 200; Soliva et al., 2007; Hemsing and Bryn, 2011; Shucksmith and Rønningen, 2011; Øian and Rønningen, 2013). These landscape values relate 
to biodiversity (Olsson et al., 2000; Kålås et al., 2010), cultural heritage and identity formation (Daugstad 2000), recreational value (Daugstad, 2008; Eiter, 2010) and economic value for fodder (Rekdal and Angeloff, 2012). Neo-productivism (Almås and Campbell, 2012) is documented in the agricultural white paper on agriculture and climate. Norway is currently developing a hybrid, repositioned productivist system, one where post-productivist (multifunctional) and neo-productivist agriculture are strengthened side-by-side (Bjørkhaug et al., 2012).

In France there is a growing interest of society in mountain grassland areas by society, due to their various functions with respect to biodiversity, the landscape and the environmentally friendly image of local products (Legeard, 2004; Masson-Maret and Vairetto, 2014). However, there seems to be a discrepancy between pastoral (and generally agricultural) associations and ecological organizations. The French pastoral association recently reaffirmed the production function of pastoralism in response to the growing interest for its ecological functions (Pluvinage, 2014). This urban vision is challenging the cultural cognitive perception by farmers of their profession. The heated debates regarding the reintroduction of wolves may be indicative for the tension between ecological and productivist positions. Ecological environmental associations promote a "cohabitation" of predators such as wolves with pastoral activities of farmers as part of "rebuilding" nature. However, farmers perceive the wolf as a major threat to the survival of their activity, despite compensations granted by the government in case of the loss of sheep to wolves (Garde et al., 2014). Here two cultures clash in a way, which is not yet reconciled. Farmers see production as the primary function of their activity, and nature conservation comes only second, while environmentalists tend to have opposite priorities.

Thus on a national level in Austria and Norway neo-productivist approaches seem to clash with multifunctionality and the provision of ecosystem services, while in France it seems rather the opposite, that farmers have to defend their production function against environmentalists.

On a case study level, there are a number of institutions and organizations governing grassland management, pressuring it to comply with societal norms depicted above. In the French case the communal organization of land management in Villar d'Arêne, helps to distribute land more equitably, taking into account technical constraints associated with the mountain terrain. The organization also decides on the farming calendar (including constraints from agrienvironmental measures, inter-annual climatic variability and its effects on grass growth) which local and transhumant farmers have to comply with (Lamarque, 2012). This organization of the land tenure agreements has made it easier to receive subsidies within the CAP and it supports the collective purchase of equipment, such as fences (Lamarque, 2012). In the Austrian case study a local farmers association manages the collective pastures in the valley as well as on the mountains. In Norway there is a legal obligation for private land owners to manage infields or to rent it to active farmers. If left unattended, the municipality has the right to redistribute the land, which so far has never been necessary.

Normative claims concerning animal welfare affect indirectly grassland management. There is a general trend towards transition from tethering of cows to free-run barns, which will become mandatory in the future. In Norway, all barns need to be free-run by 2035 and the EU-regulation for organic farmers has already restricted tethering to smallholders. Yet, in the Austrian case study, most stables date from the 1970s and have tethered systems. If these barns have to be replaced, the required investment costs are likely to lead smaller farms to stop, thus furthering the concentration process.

Another social norm considers quality of life expectations, such as taking holidays and compatibility of farming practices with off-farm labor, also indirectly affect grassland management. The possibility of taking vacations is connected to the labor intensity of the chosen farming system, the family situation or the availability of relief services (e.g. provided 
in Austria by machinery rings). Options for pluri-activity are also important, as most farmers in mountain areas cannot live from their farming activity alone. Thus, the job market in the region and the time constraints due to off-farm employment make efficient labor allocation an important consideration. It may drive farmers to adopt more labor-extensive production practices, e.g. a shift from dairy to suckler cows or to sheep, thus affecting how mountain grasslands are used. However, these production systems allow more flexible time management, enable a higher quality of life and make it easier to take holidays.

Gendered division of labor on-farm and off-farm, a typical normative institution, will thus impact how grassland plots - especially those further away from the farm - are managed, affecting timing and frequency of mowing, with possible effects on species composition. While on part-time farms in Neustift it is mostly the husband, who works outside the farm (to remain the 'bread winner'), in Oppdal and in Lautaret it is more often the wife. In both situations one member of the farming couple is engaged in off-farm employment, but the social construction of gender roles leads to the perception that a farm is run 'full-time' when the male farmer is working on the farm. Yet, gender roles, both regarding decision-making and labor-demands for the household, for caring for children and the elderly have an impact on the available labor and thus the choice how to manage the grasslands. Indeed, in those households were women remain on the farm; they find it difficult to find sufficient time to manage grasslands, especially those that are further away from the farm. As a result, mowing and haymaking is performed when the husband can find the time, rather than when it is optimal from an agronomic point of view (i.e. related to growth stage or nutrient content).

\subsection{Regulative institutions}

Different societal groups lobby for their interests to be represented in the regulative institutional elements like laws and support systems, defining what is allowed and what is not. Policy wants to maintain agricultural activity in remote areas, with environmental friendly production practices. These normative claims are codified in subsidy systems so as to preserve active farms. Even if farmers are not legally obliged to make use of subsidies, the economic situation often leaves them little choice. Especially the rules for "cross compliance" enforce a basic acknowledgement of environmental standards to be eligible for any support payments.

The major architecture of the support program is similar in all three countries, probably due to influences of global trade liberalization debates. The EU supports market production in the first pillar of the CAP and so does Norway with production and price subsidies. However, each Norwegian farmer receiving production subsidies needs to have a specific plan for the use of fertilizer (organic as well as inorganic) and a log for the use of other chemicals. The second pillar of the CAP supports rural development and agro-environmental programs, just like Norway with a National environmental program, a Regional environmental program (RMP), and Special Environmental Measures in Agriculture (SMIL). However, within the EU the agrienvironmental programs vary markedly in spite of the shared CAP framework. For instance in France, to be eligible for territorialized agri-environmental payments the farmer's parcels has to be located within a specific area, delineated on the basis of environmental stakes, while in Austria the agri-environmental program is offered nationwide.

In Austria generally agricultural and environmental objectives seem to be well aligned, due to the fact that agricultural organizations designed the measures to compensate for the price decline associated with the fundamental change of the support system at EU accession. Their underlying goal is to preserve current farming practices and to harmonize them with normative market forces. This resulted in a high participation in organic farming, which is perceived as a continuation of 'traditional' practices by farmers, and simultaneously as an indicator for 'ecologically sound' practices by other societal actors (Schermer, 2015). 
Regulative institutions may influence the management of permanent grassland in mountain areas either directly or indirectly. Direct influence is mostly exerted by policies that provide direct payments to farmers implementing measures such as alpine pasturing, or mowing of steep slopes. Indirect influences on grassland management come with a variety of regulations. For example, animal welfare regulations state that animals must have access to pasture for a certain period of time. In Austria, farmers are required to provide cattle and sheep with access to a pasture - or at least a free run - for at least 90 days per year. In Norway, sheep and goats are required to graze for a minimum of 16 weeks; cattle in tethered systems for 16 weeks and those kept in free-run barns for a minimum of eight weeks. In France there is no general rule, the period of access to summer pastures is fixed in the management plans of agri-environmental measures. In all three countries the regulations largely comply with traditional practices of pasturing on fields close to the farm in spring and autumn, and on mountain pastures in summer.

Besides laws and direct-payment systems, the regulative power of market institutions influences farmers' practices. In general, markets for agricultural commodities play a rather limited role in the decision-making of mountain farmers, as the agricultural income is more dependent on transfer payments for the provision of public goods than on revenues generated through the sale of products. For example in Tyrol (Austria) on average $86 \%$ of the agricultural income stems from public transfers payments (Land Tirol, 2014). In the French Alps the amount of direct payments is roughly equal to operational expenses.

To summarize, the analysis of institutions shows that besides the multilevel regional, national and international government structures, non-state and informal actors can significantly influence the choices made by farmers. In particular, normative and cognitive-cultural institutions can be decisive at local and regional levels, due to their strong influence on the perception of farming in society, thus influencing what grassland management practices are seen as desirable, thus strengthening or alternatively weakening farmers' sense of self-worth.

\section{Implications for the resilience of mountain grasslands}

The resilience of mountain grassland is first and foremost connected to the structural change of farms. In Norway there has been a sharp decrease in the number of farms during the last decades, whereas in Neustift so far the situation has been rather stable. In Lautaret the main decrease had happened during the 1970s and 1980, and the situation has since stabilized at a low level.

However, in the future there might be some institutional impacts increasing the concentration tendencies. One is the transition to free-run barns as already mentioned. Furthermore, although the market prices have only a limited impact on farmer practices, shifts in market organization are likely to impact the economic viability of farms. Such trends, already visible in the Austrian case study, may be reinforced by the abolition of the EU-milk quota system, which was implemented in spring 2015. The resulting lower producer prices for milk may force small scale farms especially in mountain areas to close down or at least stop milk production. The interviewed farmers see consequences for land management as knock-on effects. The remaining larger scale operations will try to rent their land as far as it is easy to manage with big machinery. Grasslands on slopes could be abandoned.

Besides these institutional influences on the farming structure, there are impacts on the resilience of management practices (Table 2). We understand resilience in this respect as (1) the ability to buffer sudden disruption, (2) to adapt to gradual changes, but also (3) to transform the farming system when the current configuration is no longer sustainable (see Darnhofer 2014). As the three case studies have shown, institutions influence farmer practices, how 
grassland is managed, in many ways. The question then is, whether and how institutions affect the resilience of mountain grassland.

Table 2: Examples of how institutions may reduce or strengthen the resilience of grassland management practices

\begin{tabular}{|l|l|l|l|}
\hline & Ability to buffer & Ability to adapt & Ability to transform \\
\hline $\begin{array}{l}\text { Regulative } \\
\text { institutions }\end{array}$ & $\begin{array}{l}\text { By providing a secure } \\
\text { income, direct payments } \\
\text { enable farmers to buffer } \\
\text { shocks (e.g. the impact of } \\
\text { drought, sudden price } \\
\text { decline). }\end{array}$ & $\begin{array}{l}\text { 5-year contracts within the CAP, } \\
\text { stipulating specific management } \\
\text { practices, limit the farmer's ability } \\
\text { to adapt practices when needed } \\
\text { (e.g. in response to weather } \\
\text { variability) }\end{array}$ & $\begin{array}{l}\text { Shifts on markets (e.g. the } \\
\text { abolition of the milk quota } \\
\text { system) reinforces } \\
\text { concentration trends } \\
\text { thereby eroding traditional } \\
\text { practices }\end{array}$ \\
\hline $\begin{array}{l}\text { Normative } \\
\text { institutions }\end{array}$ & $\begin{array}{l}\text { Mutual self-help, like } \\
\text { joint machinery use, } \\
\text { collective purchase etc. } \\
\text { may strengthen buffer } \\
\text { capacity }\end{array}$ & $\begin{array}{l}\text { Social values embedded into local } \\
\text { and regional marketing such as } \\
\text { those conveyed by direct } \\
\text { marketing customers and tourists } \\
\text { can encourage farmers to adapt at } \\
\text { farm-level as to maintain } \\
\text { traditional grassland management } \\
\text { practices }\end{array}$ & $\begin{array}{l}\text { Social values, such as } \\
\text { those linked to animal } \\
\text { welfare (e.g. free-run } \\
\text { barns) may promote a } \\
\text { transformation of animal } \\
\text { housing, but this may } \\
\text { negatively affect grassland } \\
\text { management practices }\end{array}$ \\
\hline $\begin{array}{l}\text { Cultural- } \\
\text { cognitive } \\
\text { institutions }\end{array}$ & $\begin{array}{l}\text { Mental models tend to be } \\
\text { fairly stable, ensuring that } \\
\text { practices are maintained } \\
\text { despite short-term } \\
\text { setbacks }\end{array}$ & $\begin{array}{l}\text { Internal parameters of success, like } \\
\text { the "10 000 liter cow", may } \\
\text { promote adaptations towards } \\
\text { intensification at farm-level, thus } \\
\text { threatening traditional grassland } \\
\text { management practices }\end{array}$ & $\begin{array}{l}\text { The diversity of what is } \\
\text { seen as 'thinkable' within } \\
\text { the framework of farming } \\
\text { increases, thus increasing } \\
\text { the ability of farmers to } \\
\text { creatively transform their } \\
\text { livelihood while } \\
\text { maintaining traditional } \\
\text { practices }\end{array}$ \\
\hline
\end{tabular}

\subsection{Impact on the ability to buffer shocks}

Agricultural policies and the direct payments linked to agri-environmental measures provide a fairly predictable framework for management decisions and stabilize income flows, especially since direct payments make up a large share of the agricultural income of mountain farmers. Combined with a stable off-farm income, it can strengthen the ability of farmers to buffer shocks. Traditional practices thus do not have to be questioned every time market prices drop or a family member is sick. However, while the direct-payments offered for extensive practices are a welcome source of agricultural income, they are also associated with a substantial administrative burden. This burden may demotivate smallholders, and may even reduce the likelihood of succession, as the 'paperwork' is perceived as too cumbersome.

However, the ability to buffer shocks depends not only on institutions directly related to agriculture; broader developments in the region influence the viability of farms and how they manage grassland. The influence is most directly felt through the off-farm employment, which provides an important income stream especially for part-time farms (Nettier et al., 2012). In all three case study areas, tourism provides the most obvious option for off-farm employment. If sufficient income is generated from off-farm sources, short-term shocks are less likely to lead to changes in grassland management practices. While the diversity in sources of family income may stabilize farms, it should not be forgotten that it adds to labor constrains, which may negatively affect traditional management practices. 


\subsection{Impact on the ability to adapt}

The ability to adapt (i.e. implement marginal changes) while maintaining the resilience of the grassland ecosystem, may manifest as maintaining traditional production practices that directly affect the grassland, while adapting other practices at farm-level (e.g. engaging in directmarketing). Alternatively, adaptation may involve a change of management practices, which still result in a similar ecological outcome (e.g. different mowing technology, but maintenance of timing and frequency of mowing).

As all three case studies show, mountain farmers have demonstrated a great degree of adaptive capability to maintain their farm, as a fundamental precondition for preserving permanent alpine grasslands.

However, a number of institutions impede the ability of farmers to adapt to changes such as broader societal changes or climate change. For example, EU regulations require farmers who take part in agri-environmental measures to comply with the specifications of the measure for five years. During this period, the specifications must be implemented every year, irrespective of whether or not they make sense in that particular year. For example within the measure for mowing steep slopes, they have to mow even if grass growth has been severely limited through a drought. Moreover, mowing dates are prescribed, thus preventing adaptation to earlier growth in warm / dry years. This bureaucratic imposition and inflexibility devalues farmers' expertise and restricts their ability to adapt management measures to environmental conditions.

The example of Norway shows that farmers could have a stronger say. In Oppdal the municipal administration, more specifically the bureaucrats responsible for agriculture and environment, arrange yearly 'state-of-the-art'-meetings with farmers' organizations as well as other actors related to farming. This provides a platform to discuss common concerns and future options. To some extent this mirrors the annual negotiations held at national level, where representatives of the state and of the two main farmers' organizations meet to discuss prices and other regulations. Such governance structure, both at local and national level, enables regulatory institutions to be more responsive to the changing requirements of farmers, and can thus strengthen their adaptability. However while the yearly negotiations on national level may introduce changes and adaptations on a national and regional level, they do not necessarily increase the room for maneuver on the local level.

As noted above, tourism provides a source for off-farm income in all three case study regions. However, there are different expectations what kind of adaptations will be driven by tourism in Norway and in Austria. In Oppdal the ski lift operators offer part-time jobs for farmers. While the additional income may have maintained farms, which otherwise might have been closed down, it is becoming more attractive for farmers to work in tourism, than to continue work on their farms. Interview partners raised concerns that in the long run this might contribute to downscaling or even quitting farming. The situation in quite different in Neustift, where most farms have been managed part-time for a long time and the largest share of household income is derived from off-farm employment or self-employment within the tourism sector. In contrast to the worries in Oppdal, tourism it is perceived as important for stabilizing farm numbers and not as a potential exit strategy,

The French study site shows an example of how institutions may influence the adaptation of local farming systems. The two municipalities of the French study site show diverging pathways in the face of the trend towards a ranching system where hay meadows and transitional pastures are progressively abandoned in favor of urbanization and large transhumant movements. The common pooling of hay meadows, transitional pastures and summer pastures into a landowner association in Villar d'Arêne gives local stakeholders (and especially the municipality which owns most of the agricultural land) an important power to favor the maintenance of traditional 
land use against abandonment and land speculation. In contrast in Monêtier-les-Bains, where the historical context and the geographical situation associated with the presence of a ski resort has prevented the pooling of all agricultural land into a landowner association, speculation on land threatens hay meadows in favor of secondary homes and constrains the establishment of new farms.

\subsection{Impact on the ability to transform}

Transformation at farm-level might be needed to maintain traditional grassland management practices despite broader societal changes. Ideally, to strengthen the resilience of grassland management practices, institutions should support this transformation. However, some institutional effects actually reinforce specific change trajectories leading to a transformation that threaten the resilience of grassland management practices. For instance, if the requirement to move towards free run barns is often associated with large farms, with changes in the manure management system (shift from solid to liquid manure/slurry) and in the feeding regime (less grazing on alpine pastures, more silage and more concentrate) and with new milking technology (introduction of milking robots). All these interrelated changes ultimately lead to a more intensive farming system, which directly affects grassland management (e.g. through application of slurry, an increase in the frequency of cutting). In this case the requirements of animal welfare may lead to adverse effects on plant biodiversity. Indeed, intensification is often linked with abandonment of low-yielding alpine pasture, while the use of higher yielding meadows, especially those that can easily be harvested using modern technology, is intensified.

Even when part-time farmers transform the traditional dairy system into a labor extensive farming system (like sheep) it may have similar effects. They may intensify the use of meadows close to the farm (often with the help of machinery rings) changing from traditional hay to silage, while at the same time extensifying the management on mountain pastures, as sheep do not require the same level of observation.

This bifurcation in the transformation of management practices is observed in Norway and in Austria. The French case study shows tendencies of a shift from local cattle rearing to transhumant sheep ranching, which leads to an increased demand for alpine pastures, while the pressure on the fields in the valley is rather related to settlements.

But not all observed transformations are to the detriment of traditional practices and in consequence for the ecosystem services delivered by mountain grassland. The French case study shows how institutions are purposively transformed to favor the multiple ecosystem services provided by summer pasture (productive, environmental, recreational) (Lamarque et al. 2014). As the municipality owns most of the summer pastures, it has requested the pastoral advisory service to perform a diagnosis of each pasture. The aim is to have a formal document that ensures that the array of services linked to pasture are taken into account when negotiating management plans with farmers. The integration of farmers in the discussions of management plans takes into account their needs, but at the same time raises their level of awareness of the needs of other stakeholders. The French example indicates that a change in institutions is needed to strengthen the transformative capability of farms, which is crucial for the persistence of multiple ecosystem services provided by perennial grasslands.

However, a transformation of normative institutions, which include informal societal norms, values and non-codified rules of 'good practice' may be slow. Indeed, while regulative institutions may be changed based on negotiations and formal agreements, change in normative institutions is gradual and emergent (Pahl-Wostl, 2009, pp: 265f).

Furthermore, cultural-cognitive institutions are mental models that strongly influence how a system is understood, how boundaries are delineated, how the search space for problems and 
solutions is determined. Similar to normative institutions change is not negotiated, but enacted in shared practices (Pahl-Wostl, 2009, pp: 265f). However, even cultural-cognitive institutions may over time undergo transformational change. For example in Austria farmers have gradually redefined the preservation of the cultural landscapes as one of their tasks. This shift from 'production to protection' (Schermer, 2006) happened gradually over 30 years. Such processes are part of power shifts and partly of paradigm shifts. Measures to raise local knowledge and awareness about ecological effects of farming practices may help to induce transformations in cultural cognitive institutions over time.

\section{Conclusion}

Ecosystem services of mountain grasslands depend strongly on the maintenance of traditional extensive management practices. Two trends are observed - towards intensification and towards abandonment- which both have a negative impact on the ecosystem services provided. Based on three case studies in Austria, France and Norway, we have assessed how regulative, normative and cultural-cognitive institutions affect the ability of farms to buffer shocks, adapt and transform, and thus directly or indirectly affecting how mountain grasslands are managed.

The analysis of the three case studies has shown that a variety of institutions influence farmers' options and choices, and especially their choices on how to manage mountain grasslands. To maintain traditional practices, farming not only needs to be economically viable (e.g. through combining on- and off-farm income), it also needs to be perceived as an attractive occupation and lifestyle. In other words, the maintenance of specific grassland practices must be seen as socially and culturally desirable, both, by the broader society at regional level and by farmer associations and the cultural values they promote. The maintenance of traditional grassland management practices is linked to regulatory institutions such as agricultural policies or markets, to broader social norms and to cultural-cognitive institutions held by various societal groups. These are decisive to encourage farmers to find creative ways to maintain grassland management practices. This may include revisiting what characterizes a 'good farmer', who may no longer be defined solely based on productivity, but may include pluri-activity and the conservation of the cultural landscape.

The analysis has also shown that a number of institutions have a contradictory impact on grassland management practices. Indeed, the impact of agricultural policies and animal welfare regulations is mediated by several factors at farm-level. How it is mediated by these factors will depend on the specific constellation of the farm e.g.. whether it is a full-time or part-time farm, whether it has suckler or dairy cows.

To ensure management practices that preserve the resilience of grasslands, both ecological insights of the impact of farming practices on the ecology of grassland, and an understanding of the complex interactions that affect farming practices, need to be combined. By integrating farmers in a participatory process, these changing dynamics can be taken into consideration when designing regulatory institutions, thus enabling farms to adapt and transform while maintaining traditional grassland management practices.

\section{Acknowledgement:}

This research was conducted in the frame of the BiodiERsA project "REsilience of marginal GrAsslands and biodiveRsity management Decision Support". The authors acknowledge financial support by the national funding agencies within the BiodivERsA ERA-Net Co-fund, funded under the EU's Horizon 2020 Framework Program for Research and Innovation. 


\section{References}

Adger, N. W. 2000. Social and ecological resilience: are they related? Progress in Human Geography 24 (3), 347-364 doi: 10.1191/030913200701540465

Almås, R., Campbell, H. 2012. Reframing Policy Regimes and the Future Resilience of Global Agriculture. In: Almås R., Campbell H. (Eds), Rethinking Agricultural Policy Regimes: Food Security, Climate Change and the Future: Resilience of Global Agriculture. Research in Rural Sociology and Development UK: Emerald. Vol. 18, 285-300.

Bjørkhaug, H., Almås, R., Brobakk, J. 2012. Emerging neo-productivist agriculture as an approach to food security and climate change in Norway. In Almås R., Campbell H. (Eds): Rethinking agricultural regimes. Food security, climate change and the future resilience of global agricul-ture. Research in Rural Sociology and Development. UK: Emerald. Volume 18, 211-234

Burton, R. 2004. Seeing through the 'good farmer's' eyes: towards developing an understanding of the social symbolic value of 'productivist' behaviour. Sociologia Ruralis 44(2), 195-215. DOI: 10.1111/j.1467-9523.2004.00270.x

Burton, R., Wilson, G. 2012. The Rejuvenation of Productivist Agriculture: the case for 'Cooperative neo-Productivism'. In: Almås R., Campbell (eds.): Rethinking agricultural Policy Regimes: Food security, climate change and the future resilience of Agriculture. Research in Sociology and Development Vol.18, 51-72.

Darnhofer, I. 2014. Resilience and why it matters for farm management. European Review of Agricultural Economics, 41 (3), 461-484. DOI: 10.1093/erae/jbu012

Daugstad, K. 2000. Mellom romantikk og realisme. Om seterlandskapet som ideal og realitet. Dr. polit.-avhandling, Geografisk institutt, SVT-fakultetet, NTNU.

Daugstad, K. 2008. Negotiating landscape in rural tourism in Norway. Annals of Tourism Research 35, 402-426.

Daugstad, K., Rønningen, K., Skar, B. 2006. Agriculture as an upholder of cultural heritage? Conceptualizations and value judgements - A Norwegian perspective in international context. Journal of Rural Studies, 22, 67-81. DOI:10.1016/j.jrurstud.2005.06.002

Davidson D. 2010. The applicability of the concept of resilience to social systems: Some sources of optimism and nagging doubts. Society and Natural Resources 23, 1135-1149. DOI: $10.1080 / 08941921003652940$

Deboeuf, E. 2009. Adaptabilité des systèmes d'élevage de haute-montagne à des aléas. Le cas de Villar d'Arène - Parc National des Ecrins, Hautes-Alpes. Mémoire de fin d'étude d'Ingénieur, ENITA de Clermont-Ferrand

EEA 2002. Europe's biodiversity-Biogeographical regions and seas. Biogeographical regions in Europe: The Alpine region-Mountains of Europe. European Environment Agency, Copenhagen.

http://www.eea.europa.eu/publications/report_2002_0524_154909/biogeographicalregions-in-europe/alpine.pdf/view; (accessed last 18.Nov 2015).

Eiter, S. 2010. Landscape as an Area Perceived through Activity: Implications for Diversity Management and Conservation. Landscape Research 35(3), 339-359. DOI: $10.1080 / 01426391003746531$

Engler, R.; Randin, C. F.; Thuiller, W.; Dullinger, S.; Zimmermann, N. E.; Bastos Araujo, Miguel; Pearman, P. B.; Le Lay, G.; Piedallu, C.; Albert, C. H.; Choler, P.; Coldea, G.; de Lamo, X.; Dirnböck, T.; Gégout, J-C.; Gómez-Garcia, D.; Grytnes, J.; Heegaard, E.; 
Høistad, F.; Nogues, David Bravo; Normand, S.; Puscas, M.; Sebastià, M-T.; Stanisci, A.; Theurillat, J-P.; Trivedi, M.; Vittoz, P.; Guisan, A. 2011. 21st century climate change threatens mountain flora unequally across Europe. Global Change Biology, 17(7), 23302341. DOI: $10.1111 /$ j.1365-2486.2010.02393.x

Folke, C. 2006. Resilience: The emergence of a perspective for social-ecological systems analyses. Global Environmental Change 16, 253-267

DOI: $10.1016 /$ j.gloenvcha.2006.04.002

Garde, L., Dimanche. M., Lasseur. J. 2014. Permanence and changes in pastoral farming in the Southern Alps. Journal of Alpine Research 102(2), 2-12. DOI : 10.4000/rga.2416

Grêt-Regamey A., Brunner S. H., Kienast F. (2011) Mountain Ecosystem Services: Who Cares? Mountain Research and Development 32(1), 23-34. DOI: http://dx.doi.org/10.1659/MRD-JOURNAL-D-10-00115.S1

Groier M. (2007) Permanent Grassland in Change: Aspects of Grassland Farming in Austria. [online] URL: http://www.mtnforum.org/sites/default/files/publication/files/876.pdf (accessed last 18.Nov 2015).

Heißenhuber, A. 2010. Multifunktionalität - mehr als ein Schlagwort? Ausblicke- Magazin für den ländlichen Raum 2, 6-9.

Hemsing, L. Ø. And Bryn, A. 2011. Changes in landscape and vegetation heterogeneity of rural Norway. In: Nesheim, L. (Ed.), Biodiversity in agriculture - lessons learned and future directions. Nordic Association of Agricultural Scientists, Stockholm, NJF Report 7(1), 33-38.

Holling, C.S. 2001. Understanding the complexity of economic, ecological and social systems. Ecosystems 4: 390-405. DOI: 10.1007/s10021-001-0101-5

Hovorka G. 2011. Die Evaluierung der Ausgleichszulage für naturbedingte Nachteile. BABF, Wien Facts\&Features Nr. 46

Kålås, J. A., Viken, Å., Henriksen, S. and Skjelseth, S. (eds) 2010. The 2010 Norwegian Red List for Species. Norwegian Biodiversity Information Centre, Trondheim.

Körner C. 2000. The Alpine life zone under global change. Gayana Botanica 157(1). http://dx.doi.org/10.4067/S0717-66432000000100001.;

Land Tirol 2014. Bericht zur Lage der Tiroler Land- und Forstwirtschaft 2013, Amt der Tiroler Landesregierung,Gruppe Agrar, Innsbruck

Lamarque, P. 2012. Couplage écosystème-système socio-économique appliqué aux prairies de montagne via les services écologiques : mécanismes et dynamique. $\mathrm{PhD}$, Université Joseph Fourier, Grenoble

Lamarque P.; Meyfroidt, P,; Nettier, B.; Lavorel, S. 2014. How Ecosystem Services Knowledge and Values Influence Farmers' Decision-Making PLoS ONE 9(9), 107572. doi:10.1371/journal.pone.0107572

Legeard, J.P. 2004. Pastoralisme et contractualisation agri-environnementale. L'expérience des operations conduits en Provence-Alpes-Côte d'Azur. Fourrages 179, 383-392.

Masson-Maret H, Vairetto A. 2014. Patrimoine naturel de la montagne: concilier protection et développement. Rapport d'information sur la protection et la mise en valeur du patrimoine naturel de la montagne, ${ }^{\circ} 384$, Sénat, Session ordinaire de 2013-2014, Commission du développement durable, des infrastructures, de l'équipement et de l'aménagement du territoire. Paris: Sénat: 142p. 
MA [Millenium Ecosystem Assessment]. 2005. Ecosystems and Human Well-Being: Current State and Trends. Washington, DC: Island Press;

Nettier, B., Dobremez, L., Coussy, J.-L. \& Romagny, T. 2010. Attitudes des éleveurs et sensibilité des systèmes d'élevage face aux sécheresses dans les Alpes françaises. Revue de Géographie Alpine / Journal of Alpine Research, 98(4), https://rga.revues.org/1294 DOI: $10.4000 /$ rga. 1294

Nettier, B., Dobremez, L., Lamarque, P., Eveilleau, C., Quétier, F., Véron, F. \& Lavorel, S. 2012. How would Farmers in the French Alps Adapt their Systems to Different Drought and Socio-economic Context Scenarios? 10th European IFSA Symposium, Aarhus, Denmark.

http://ifsa.boku.ac.at/cms/fileadmin/Proceeding2012/IFSA2012_WS3.1_Nettier.pdf (accessed last 18.Nov 2015).

North, D. 1990. Institutions, Institutional Change and Economic Performance. Cambridge University Press, Cambridge. 159p.

Øian, H. and Rønningen, K. 2013. Utvalgte kulturlandskap - mellom landbruksdrift, endring, forståelse og mening i landskapet. UTMARK, www.utmark.org, No 12009.

Olsson, G. A., Austrheim G., Grenne, S.N. (2000), "Landscape change patterns in mountains, land use and environmental diversity, Mid-Norway 1960-1993", Landscape Ecology, vol. 15 , no. 2 , pp. $155-170$.

Oppdal Municipality 2013a. Fakta om Oppdal. http://www.oppdal.kommune.no/Global-meny/OmOppdal/Fakta-om-Oppdal (accessed last 18.Nov 2015).

Pahl-Wostl, C. 2009. A conceptual framework for analyzing adaptive capacity and multi-level learning processes in resource governance regimes. Global Environmental Change 19(3), 354-365. DOI:10.1016/j.gloenvcha.2009.06.001

Pistrich, K. and Wyrtrzens, H. K. 2005. Leitbildanalyse und Funktionsprofil für das österreichische Grünland auf nationaler und lokaler Ebene. Jahrbuch der Österreichischen Gesellschaft für Agrarökonomie, Band 10, pp. 107-126. Fakultas. www.boku.ac.at/oega

Pluvinage J. 2014. Espaces pastoraux, espaces de productions agricoles. Pastum Hors-Série. Association Française de Pastoralisme et Cardère éditeur. 108 p

Pötsch, E.M. 2010. Multifunktionalität und Bewirtschaftungsvielfalt im Grünland. 16. Alpenländisches Expertenforum zum Thema "Biodiversität im Grünland", Gumpenstein, LFZ Raumberg-Gumpenstein, 11. März 2010, 1-10.

Quétier, F., Lavorel, S., Thuiller, W., Davies, I.D. 2007. Plant trait-based assessment of ecosystem service sensitivity to land-use change in mountain grasslands. Ecological Applications, 17, 2377-2386.

Quétier, F., Rivoal, F., Marty, P., De Chazal, J., Lavorel, S. (2010) Social representations of an alpine grassland landscape and socio-political discourses on rural development. Regional Environmental Change, 10, 119-130. DOI: 10.1007/s10113-009-0099-3

Rekdal, Y., Angeloff, M. 2012. Jordvern i utmark. Sau og Geit nr 3/2012.

Rickards. L., Howden. S. M. 2012. Transformational adaptation: agriculture and climate change. Crop \& Pasture Science 63, 240-250. http://dx.doi.org/10.1071/CP11172

Schermer, M. 2006. Regional development: through organic territory: ecoregions in Austria. In: Holt G., Reed M. (Eds), Sociological Perspectives of Organic Agriculture: From Pioneer to Policy. CABI, pp. 229-244 
Schermer, M. 2015. From 'Food from Nowhere' to 'Food from Here': Changing ConsumerProducer Relations in Austria.. Agriculture and Human Values 32(1), 121-132. DOI 10.1007/s10460-014-9529-z

Schröter, D., Cramer, W., Leemans, R., Prentice. I.C., Araujo, M.B., Arnell, N.W., Bondeau. A., Bugmann, H., Carter, T.R., Gracia, C.A., de la Vega-Leinert, A.C., Erhard, M., Ewert, F., Glendining, M., Hause, J.I., Kankaanpää, S., Klein, R., Lavorel, S., Lindner M., Metzger, M., Meyer, J., Mitchell, T., Reginster, I., Rounsevell, M., Sabaté, S., Sitch, S., Smith, B., Smith, J., Smith, P., Sykes, M., Thonicke, K., Thuiller, W.. Tuck, G., Zaehle, S. 2005. Ecosystem service supply and vulnerability to global change in Europe. Science 310, 1333-1337. DOI: 10.1126/science.1115233

Scott, W. R. 2008. Institutions and Organizations $3^{\text {rd }}$ ed. Sage Publications Thousand Oaks. 266 p.

Shucksmith, M. Rønningen, K. 2011. The Uplands after neoliberalism? - The role of the small farm in rural sustainability. Journal of Rural Studies 27: 275-287.

Soliva, R., Rønningen, K., Bella, I., Bezak, P., Cooper, T., Flø, B.E., Marty, P., Potter, C. 2008. Envisioning upland futures: Stakeholder responses to scenarios for Europe's mountain landscapes. Journal of Rural Studies 24, 56-71.

DOI:10.1016/j.jrurstud.2007.04.001

Sutherland Lee-Ann, Darnhofer, Ika (2012) Of organic farmers and 'good farmers': Changing habitus in rural England. Journal of Rural Studies 28(3), 232-240. DOI: 10.1016/j.jrurstud.2012.03.003

TEEB 2010. The Economics of Ecosystems and Biodiversity: Mainstreaming the Economics of Nature: A Synthesis of the Approach, Conclusions and Recommendations of TEEB. [online] URL: http://doc.teebweb.org/wpcontent/uploads/Study\%20and\%20Reports/Reports/Synthesis\%20report/TEEB\%20Synt hesis\%20Report\%202010.pdf (accessed last 18.Nov 2015).

Walker, B., Holling, C. S., Carpenter, S. R. Kinzi, A. 2004. Resilience, Adaptability and Transformability in Social-ecological Systems. Ecology and Society 9(2), 5. [online] URL: http://www.ecologyandsociety.org/vol9/iss2/art5/

Young, O. R., King, L. A., Schroeder, H. 2008. Institutions and Environmental Change: Principal Findings, Applications, and Research Frontiers. MIT Press, Cambridge, Mass. $373 \mathrm{p}$. 